\title{
Osmanlı Devleti'nden Günümüze Parlamentarizm ve Parlamenter Rejime Müdahaleler - Muhtıra, Darbe ve Darbe Girişimleri Üzerine Bir Analiz
}

\author{
Parliamentarism From Ottoman Empire To The Present And Interventions \\ To The Parliamentary Regime - An Analysis on Military Memorandum, \\ Military Coup and Military Coup Initiatives
}

İsmail SAFi'

https://orcid.org/0000-0002-3672-5754

öz

Osmanlı Devleti I. Meşrutiyet ile parlamenter rejime geçmesine karşın bu süreç kısa sürmüş, 30 yılı aşkın istibdat döneminin ardından, bir daha vazgeçmemek üzere, 1908 yılında parlamenter rejime geçişi sağlamıştır. II. Meşrutiyet dönemi ile birlikte Batıcılık fikri toplumsal ve siyasal hayatta önem kazanmış ve Osmanlı Devleti'nde siyasetin temel hareket noktas olmuştur. Böylece toplumda ve siyasal kurumlarda yenileşme ve batılılaşma süreci işletilmiştir. Yönetimde meydana gelen değişim, bürokraside ve toplumun tüm tabanında hissedilmiş ve ilerleyen dönemde Türk siyasal hayatını etkileyen olaylar zincirinin başlangıç noktasını oluşturmuştur.

Millî Mücadele sonrasında Osmanlı Devleti'nin yerine kurulan Türkiye Cumhuriyeti II. Meşrutiyet'in siyasal ve toplumsal alandaki politikalarını miras olarak almış ve ilerleyen dönemde parlamenter geleneği devam ettirmiştir. Fakat Osmanlı Devleti'nden günümüze kadar devam eden parlamentarizmin işleyişi kendi haline bırakılmış, özellikle ordu tarafından birçok kez kesintiye uğratılmış ya da uğratılmaya çalışılmıştır. Sonuçta Türk siyasal hayatında askerin siyasete müdahalesi, siyaseti vesayet altına alması ya da alma girişimleri Osmanlı'dan Cumhuriyet'e bir miras olarak geçmiş ve süreklilik kazanmıştır.

Bu çalışmada Osmanlı Devleti'nden günümüze yaşanan parlamenter rejimin işleyişine yönelik olarak müdahaleler ele alınmış ve bunun sebep ve sonuçlarını ele alan bir analiz gerçekleştirilmiştir.

Anahtar Kelimeler: Parlamentarizm, Muhtıra, Darbe, Darbe Girişimi.

\begin{abstract}
Although Ottoman Empire passed to the parliamentary regime with the First Constitutional Era, this process was short-lived. After more than 30 years of oppression in 1908, the transition to the parliamentary regime was ensured. The idea of Westernism gained importance in social and political life with the Second Constitutional Era, and it has become the central point of politics in Ottoman Empire. Thus, the process of renewal and westernization was carried out in society and in political institutions. The change in the administration has been visible in the bureaucracy and every fragment of society, and it constituted the beginning of a chain of events that affects deeply Turkish political life.
\end{abstract}

Following the collapse Ottoman Empire and the Independence War, Republic of Turkey was established and inherited the political and social policies of the Second Constitutional Era as a legacy and continued the parliamentary tradition. However, the functioning of parliamentarism, which has continued until today, in Ottoman Empire has been left to itself, and it has been interrupted or attempted to be interrupted by the army many times. In the end, the military intervention in the Turkish political life, the attempts to take politics under guardianship and its attempts in that sense have been transmitted as legacy of Ottoman Empire and becomes constant.

In this study, the interventions to the functioning of the parliamentary regime from Ottoman Empire to the present have been discussed and an analysis has been carried out to address the causes and the consequences of this phenomena.

Key Words: Parliamentary, Military Memorandum, Military Coup, Military Coup Initiatives 


\section{GíRiş}

Türk siyasal yaşamında, Osmanlı Devleti'nde kuruluş döneminden başlayarak yükseliş dönemini de içine alan dönemde henüz parlamenter demokrasi geleneğinin oluşmadığını söyleyebiliriz. Bu süreçte mutlak monarşi olarak adlandırdığımız siyasal rejim mevcuttur ve parlamentarizmin oluşabileceği bir zemin oluşmamıştı. Çünkü parlamento olmadığı için ne parlamento içi ne de parlamento dışında siyasal iktidar karşısında onu denetleyen bir muhalefet söz konusuydu. Kısaca toplumda monarka karşı harekete geçmek ve onun iktidar alanını sınırlandırmak düşüncesi ve eylemleri henüz oluşmamıştı.

Tanzimat dönemi ile birlikte muhalif hareketlerin oluşmaya başladığını görmekteyiz. Batılı devletlerin baskısı sonucu yapılan reform hareketleri ile ilk muhalif hareketler ortaya çıkmaya başlamıştır. Tanzimat döneminde muhalif hareketlerin doğmasında yurt dışında eğitim gören ve kendilerini Batılılaşmaya adamış olan aydın kesimin önemli katkıları vardı (Heper, 1974: 53). Başka bir ifadeyle devletin içinde bulunduğu çöküş sürecinin farkında olan ve bu durumdan kurtulmak için çareler arayan aydınlar kendi aralarında gizli bir şekilde örgütlenerek muhalefet hareketi oluşturmayı başarabilmişlerdi (Tunaya, 1995: 81-88). Avrupa'da yetişmiş olan Osmanlı aydın kesimi, yurt dışından aldıkları eğitimin de etkisiyle, çağdaş gelişmelere paralel olarak, toplumsal ve siyasal yapıdaki çöküşü durdurmak için eski rejimi ortadan kaldırarak yerine parlamentoyu yani meşruti monarşiyi getirmek istemişlerdi. Başka bir ifadeyle uzun vadede hedef parlamenter demokrasiyi yerleştirmek ve kalıc kılmaktı. Nihayetinde Mithat Paşa'nın da katkısıyla, 23 Aralık 1876'da Kanun-i Esasi ilan edilmiş ve parlamentarizme geçildi (Aydın, 2001: 329). Il. Abdülhamit, Rus Savaşı'nı bahane ederek Şubat 1878'de Meclisi kapattı, parlamentonun varlığına son verdi ve Osmanlı aydınlarının birçoğunu da tutuklattı. Bunun sonucunda Padişah, 1878'den 1908'e kadar sürecek olan istibdat ya da kişisel egemenlik dönemini başlattı. Böylece henüz filiz halindeki parlamentarizm daha olgunlaşma sürecini yaşayamadan ortadan kaldırılmıştır (Mardin, 1991: 179).

Böylece Türk siyasal yaşamının bir ilki olan parlamentarizmin varlığı çok kısa sürmüştür. Parlamentarizm taraftarı olan aydınların faaliyetlerine izin verilmeyince onlar da yurt dışına kaçarak, basın aracılığı ile muhalif hareketlerini devam ettirmişlerdir. Kendilerini, 'Batılılaşma taraftarı aydınlar' olarak nitelendiren bu kadrolar yurt dışında örgütlenme faaliyetlerini yönlendirmişler ve söz konusu örgütlenmeler günümüze kadar etkilerini devam ettirecek olan "ittihatç" hareketin (Ittihat ve Terakki Cemiyeti) doğmasına neden olmuştur. Itttihat ve Terakki Cemiyeti mensuplarının faaliyetleri sonucu 1908'de Meclis tekrar açılmış ve parlamentarizme yeniden geçilmiştir. Cumhuriyetle birlikte de çağdaş parlamenter demokrasinin inşası tamamlanmıştır.

Osmanlı Devleti'nde parlamenter demokrasinin yerleştirilip geliştirilmesi hep ordu mensupları aracılığıyla olmuştur. Gerek I. Meşrutiyet gerekse II. Meşrutiyet'in ilanında hep ordu mensupları en önemli görevleri üstlenmişlerdir. Aynı şekilde Büyük Millet Meclisi'nin oluşmasında aktif rol oynayanların da ordu mensubu olduğunu görmekteyiz. Kısaca ifade etmek gerekirse Türk siyasal yaşamında parlamentarizm ordu tarafından yerleştirilmiş ve geliştirilmiştir. Ancak ordu mensupları parlamentarizmin Türk siyasal kültürüne hâkim olmasını sağlarken aynı zamanda birçok kez parlamenter rejimin işleyişine müdahale etmişler ve parlamenter demokrasinin kesintiye uğramasına sebep olmuşlardır. Özellikle Osmanlı Devleti döneminde yeniçeriler daha sonra modernleşme dönemiyle birlikte farklı isimler altında askerler, askeri ayaklanma ya da darbeler şeklinde siyasal sisteme müdahale etmeye başlamışlar ve bu müdahaleler genelde padişah değişimi ile sonuçlanmıştır.

Türk siyasal yaşamında ordunun siyasete müdahalesi, siyaseti vesayet altına alması Osmanlı Devleti'nden Türkiye Cumhuriyeti'ne bir miras olarak geçmiştir. Devletin kuruluş aşamasında etkin role sahip olan silahlı kuvvetler mensupları, kendilerini rejimin bekçisi olarak görmüşler ve parlamenter rejimden sapma olduğunu iddia ederek sistemin işleyişine müdahale etmişlerdir. Illk zamanlar Mustafa Kemal Paşa ve İsmet Paşa dönemlerinde, onların askeri kişiliklerinin de etkisiyle siyasal hayata müdahale etmemişlerse de çok partili hayata geçildikten sonra, hatta günümüze kadar sık sık siyasal sisteme müdahale etmeye başlamışlardır.

$\mathrm{Bu}$ çalışmada ordunun parlamenter rejimin işleyişine müdahaleleri ve parlamenter demokrasiyi kesintiye uğratma süreçleri incelenecek ve bunun sebep ve sonuçları üzerine bir analiz gerçekleştirilecektir. Çalışmada yöntem olarak literatür tarama modeli kullanıımıştır. Ayrıca çalışma basın taraması ve hatıratlar gibi birincil kaynaklar üzerinden desteklenmiştir. 


\section{Kavramsal Çerçeve: Muhtıra, Darbe ve Darbe Girişimi}

Çalışmada öncelikli olarak askerlerin parlamenter demokrasiye müdahale yöntemleri olarak nitelendireceğimiz kavramların açıklanması gerekmektedir. Bu kapsamda darbe, askeri darbe, muhtıra, darbe girişimi, kalkışma gibi kavramların açıklanması gerekmektedir. Askerlerin siyasal sisteme müdahale yöntemlerini doğrudan müdahale yöntemleri ve dolaylı müdahale yöntemleri olarak ikiye ayırabiliriz.

\subsection{Doğrudan Müdahale Yöntemleri}

Ordunun siyasal rejime doğrudan müdahale yöntemleri darbe, darbe girişimi ve kalkışma olmak üzere üçe ayrılmaktadır.

\subsubsection{Darbe}

En çok bilinen doğrudan müdahale yöntemi "darbe"dir. Darbe, Türk Dil Kurumu tarafından "bir ülkede baskı kurarak, zor kullanarak veya demokratik yollardan yararlanarak hükümeti istifa ettirme veya rejimi değiştirecek biçimde yönetimi devirme işi" olarak tanımlanmıştır (TDK, 2017). Yahya Akyüz, darbe kavramını "Bir devletin siyasal, sosyal ve ekonomik yapısını ya da yönetim düzenini değiştirmek amacıyla hukuk kurallarına ve kanunlara uymaksızın zora dayalı ve kuvvet kullanarak yapılan geniş halk hareketi" olarak tanımlamaktadır (Akyüz, 1989: 9). Murat Sarıca ise kavramın tanımlanmasında ani, birdenbire, beklenmeyen şekilde geçekleşmesine ve hukuk dışılığına vurgu yapmaktadır:

"Devletin temel kanunu olan anayasanın kendi içinde belirtilen değiştirilme kuralları yerine aniden ve hukuk dışı yöntemlerle ortadan kaldırılmasıdır"(Sarıca, 1995: 5).

Sarıca'nın tanımı siyasal anlamda intilali ifade etmektedir. Halkın ekonomik, politik ve sosyal alanlardaki isteklerinin karşılık bulamaması sonucu toplumda huzursuzluğun artması, refah seviyesinin düşmesi sonucu ihtilal ortamının doğduğuna dikkat çekmektedir (Sarıca, 1995: 5).

Samuel Paul Huntington 1968'de yayınladığı Değişen Toplumlarda Siyasal Düzen adlı kitabında üç farklı darbe türünden bahsetmektedir:

a) Birincisi "Devrim darbesi" olarak adlandırılan darbedir. Bu darbe çeşidi devrimci bir grup-sivil, asker veya siyasi muhalefetten oluşur. Hükümeti devirip kendilerini yeni liderler olarak konumlandırmayı amaçlamaktadır. Rusya'da Çarlık rejimini yıkıp yerini alan Bolşevik Devrimi, devrim darbesinin bir örneğidir (Huntington, 1968: 25-29).

b) İkinci darbe türü ise "Vesayet darbesi" olarak adlandırılmıştır. Bir seçkin elit, başka bir seçkin elitin gücünü eline geçirdiğinde vesayet darbesi meydana gelir. Bir cumhurbaşkanı veya Kralın yerinden indirilmesi durumunda ordu generali, genellikle eylemin ulusal fayda için olduğunu söyleyerek durumu haklı göstermeye çalışır. Eski Mısır Cumhurbaşkanı Muhammed Morsi'nin General Abdel Fattah el-Sisi tarafından tutuklanması bazıları tarafından bir vesayetçi darbe olduğu şeklinde değerlendirilmiştir.

c) Üçüncü tür darbe ise "Veto Darbesi"dir. Bir veto darbesi, radikal bir siyasi değişimden statükoyu korumak için ordu müdahale ettiği zaman ortaya çıkmaktadır. Buna örnek olarak, Peru Cumhurbaşkanı Alberto Fujimori, ülkenin yasama organını geçici olarak dağıtma niyetinde olduğu açıkladıktan sonra 1992 yılında bir müdahale ile görevinden alınmasıdır (El-Nawawy vd, 2016: 2280-2296).

Yukarıda verilen açıklamalar doğrultusunda darbe; devletin ordu üyeleri ya da bir ulusal hükümet üstü kurumu tarafından ele geçirilmesi olarak tanımlanabilir. Modern tarihin en dikkate değer örneklerinden birisi 1799 yılında Napolyon Bonapart'ın Fransız hükümetini devirmesidir. Ayrıca darbe, hükümetin küçük bir grup tarafından ani ve şiddet yoluyla devrilmesi olarak da açıklanabilir. Darbenin temel ön şartı, silahlı kuvvetlerin, polisin ve diğer askeri unsurların tamamının veya bir kısmının kontrolüdür. O halde darbeden kastedilen askeri darbe kavramıdır. Ordu devletin milli savunması ile ilgili bir kurum olması nedeniyle elinde silah gücü bulunduran bir devlet kurumudur. Bu güç onun bir baskı grubu olarak yer almasında önemli etken olmaktadır. Demokratik bir yönetimde ordunun devlet içerisinde bir güç olarak kendini konumlandırması, kuvvet kullanma yoluyla sivil iktidarlara ve siyasi karar alma mekanizmasına müdahale etmesi askeri darbe olarak nitelendirilmektedir:

"Mevcut hükümetin çok itinayla ve ayrıntılı bir şekilde sistematik hazırlanmış bir plan çerçevesinde ordunun top yekûn ya da belirli bir kesimi tarafından ani bir darbeyle, zor kullanarak devrilmesi ya da değiştirilmesi eylemidir. Ayrıca bir siyasal güç tarafından mevcut siyasal iktidar sahiplerinin şiddet ve zor kullanılarak hukuk dışı yollardan değiştirilmesi çabası olarak ta tanımlayabiliriz. Daha doğru bir ifadeyle askeri darbeler gasp niteliği taşıyan bir tür siyasal şiddet eylemleridir (Atay, 1998: 8). 
Askeri darbede amaç iktidarda kalıcı olmak ya da çıkar sağlayıcı amaçları kollamak değildir. Askeri darbe/ intilalin amacı genellikle ordunun benimsediği daha önceki sosyo-ekonomik statükonun korunması, resmî ideolojinin yerleştirilmesi ve muhafazası ve daha çok çıkar amacı gütmeyecek şekilde, bu amaçlara aykırı görülen sivil toplum örgütlerinin ve onların yönetici gruplarının temizlenmesine ve toplumun istenilen şekilde hızla dönüştürülmesine kendisini adamış yöneticilerin yönetimde yer almasına hizmet etmektir (Ince, 27).

Devlet mekanizması içerisinde elinde bulundurduğu silahlı kuvveti halkın sivil iradesine karşı kullanmak yoluyla gerçekleştirdiği bu eylemler, aslında bir hükümet darbesinden çok halkın iradesine yapılan bir etkidir. Bu eylemler yoluyla ordu devletin gerçek sahibi imajını vermekte ve halkın iradesine karşı otoriter bir güç olarak ortaya çıkmaktadır.

Türk siyasal yaşamında görülen darbeler askeri darbelerdir ve ordu/silahlı kuvvetler tarafindan gerçekleştirilmiştir. Ordu darbe yapma gücünü elinde bulundurduğu silahlı gücünden almaktadır. Ordu her zaman siyasal rejimin işleyişine doğrudan müdahale etmemiş bazen de dolaylı bir şekilde müdahale etmiştir. Bunlar darbe girişimi ve kalkışmadır.

\subsubsection{Darbe Girişimi}

Darbe girişimine gelince, darbe kavramı üzerinden hareket ederek "Bir ülkede baskı kurarak, zor kullanarak veya demokratik yollardan yararlanarak hükûmeti istifa ettirme veya rejimi değiştirecek biçimde yönetimi devirme girişimi" olarak tanımlanabilir (TDK, 2017). Kısaca darbe eyleminin gerçekleştirilmeye çalışı ması darbe girişimi olarak tanımlanmaktadır. Genellikle elinde silahlı bir güç bulunduran bir kurumun zorla hükümeti ve siyaseti tasfiye girişimidir. Ancak bazı zamanlarda isyanların darbe girişimine evrildiği görülmektedir. Silahlı kuvvetler içinden bir grubun eylemi ya da top yekûn bir girişimdir.

\subsubsection{Kalkışma}

Kalkışmaya gelince, "Bir ülkede gücü elinde bulunduran grubun zorla yönetimi ele geçirmek için faaliyete geçmesi" olarak tanımlanabilir. TDK'de kalkışmanın açıklaması "İsyan, ayaklanma, kıyam" olarak verilmektedir (TDK, 2017). İsyan ve ayaklanma devlet otoritesine karşı yapılan bir işlemdir. Bu kalkışma genellikle hükümetin ele geçirilmesi amacıyla yapılmaktadır.
Kalkışma siyasal otorite karşı yapılan ve demokratik olmayan yöntemlerin kullanıldığı bir girişimdir. Kalkışmadan arzulanan şey devletin kurumlarını illegal bir şekilde ele geçirmek ve kalkışmanın amaçları doğrultusunda karışıklık çıkarmaktır. Kalkışmadan beklenilen amaç, ülke çapında karışıklık çıkarmak ve elde edilen bu karışıklık ile siyasal yönetimin otoritesinin ortadan kalktığını ve artık iş yapamaz hale geldiğini göstermeye çalışmaktır. Amaç insanların siyasi otoriteye ve devlet yönetim organlarına karşı bir güvensizliği aşılamak ve bu yolla isyan başlatmaktır. Kalkışma ile darbe girişiminin temel farkı, kalkışmada sivil kanadın ağılıkı olması ve daha etkin rol üstlenmesidir. Başka bir ifadeyle kalkışmada görüntü bir darbe girişimi şeklindedir; fakat perde arkasında olayları organize eden ve planlayan bir örgüt vardır. Rumeli Kalkışması'nda perde arkasında Ittihat ve Terakki Cemiyeti'nin, 15 Temmuz Kalkışması'nda da FETÖ'nün olması gibi.

\subsection{Dolaylı Müdahale Yöntemleri}

Şu ana kadar askerin siyasal rejime doğrudan müdahale yöntemlerinden bahsedildi. Bunların dışında dolaylı müdahale araçları ve yöntemleri de vardır. Bunlardan ilki Post-modern darbedir.

\subsubsection{Post-modern Darbe}

Post-modern darbe, silahlı kuvvetler üst yönetiminin sivil yönetime karşı doğrudan etkide bulunmadan dolaylı olarak yaptığı darbe şeklidir. Bu tür darbelerde, askeri bir yetkilinin o sırada rahatsız olunan herhangi bir (ekonomik, sosyal, siyasal) durum üzerine açıklamalar yapması, askerlerin hoşuna gitmediğini söyleyerek iktidarı uyarması veya birkaç askeri unsurun üstü kapalı eylemde bulunması ile gerçekleşir. Türkiyesdeki 28 Şubat olayı, çoğu uzman tarafından post-modern darbe olarak kabul edilmektedir.

\subsubsection{Muhtıra}

Muhtıra ordu mensuplarının siyasal hayata müdahale etme girişimlerinden bir tanesidir. Darbeden farkı silahlı kuvvetlerin burada siyasal hayata fiili bir müdahalesi söz konusu değildir; dolaylı ve ileriye dönük bir müdahale söz konusudur. Silahlı kuvvetlerin üst düzey yönetim kadrosu siyasetin ve ülkenin gidişatından duydukları rahatsızıı̆ı yazılı ve bir şekilde sivil yöneticilere yani siyasal iktidar mensuplarına bildirirler. Yazılı uyarının içerisinde yalnızca ülkenin gidişatından duyulan rahatsızlık değil bunun yanında sorunların acil çözümü konusunda da bir uyarı ve 
tehditte vardır. Tehditten kasıt sorunlar çözülmezse askerin yönetimi sivillerinden geçici süre alacağı yani darbe tehdidi vardır (Ince, 28). Terminolojik olarak incelendiğinde muhtıra kelimesi "Herhangi bir şeyi hatırlatmak, uyarmak amacıyla yazılan yazı" olarak tanımlanmaktadır. Ayrıca "Bir devletin başka bir devlete politik sorunlarla ilgili olarak yolladığı uyarı yazısı, memorandum, nota" şeklinde ikinci bir anlamı da bulunmaktadır. Kelime anlamının uyarmak olması ve askeri organlar tarafından verilmesi bu terimin genel kullanımı ile birlikte bir baskı aracı haline getiren bir uygulama olmasını sağlamıştır. Devletin bir kurumunun devletin yönetim mekanizmasına verdiği bir uyarısı olarak karşımıza çıkan bu işlem anlamı açısından bakıldığında bir müdahale mekanizması olarak kullanılmaktadır (Devran ve Özcan, 2016: 7-20).

\subsection{3. e-Muhtıra}

Son dolaylı müdahale yöntemi e-muhtıra'dır. E-muhtıra ilk defa Türkiye'de rastladığımız bir muhtıra türüdür. Türk Silahlı Kuvvetleri'nin 27 Nisan 2007 gecesi internet sitesi aracılığıyla 11. Cumhurbaşkanı Abdullah Gül'ün, meclis tarafından Cumhurbaşkanı seçilmesi süreci ile ilgili yayınladığı bildiri e-muhtıra olarak tanımlanmaktadır (www.darbeler.com). Ana muhalefet partisi CHP'nin Cumhurbaşkanlığı seçimleriyle ilgili ilk oylamayı Anayasa Mahkemesi'ne götürdüğü gece saat 23:17 itibariyle Genelkurmay Başkanlığı internet sitesinde yayınlanan basın açıklamasında, "Türk Silahı Kuvvetleri'nin (TSK) laikliğin savunucusu olduğu" hatırlatılarak; bu konumunun kararlılıkla sürdürüleceği ve gerektiğinde bu görevin eksiksiz yerine getirileceği sert bir şekilde dile getiriliyordu. Bu bildiriyi daha önceki askeri vesayet bildirilerinden ayıran ve ona "e" takısı eklenmesine neden olan özellik kullanılan aracın farklılığıdır. Yani elektronik ortamdan duyurulması ve doğrudan siyasal iktidara değil halka duyurulmasıdır.

\section{Osmanlı Devleti'nde Parlamenter Rejime Müdahaleler}

\section{1. Çırağan Vakıası/Baskını Darbe Girişimi}

II. Abdülhamit'e karşı yapılan darbe girişimlerinin ilki olması nedeniyle önemli olan Çırağan Vakıası, Üsküdar Cemiyeti tarafından sarıklı devrimci olarak anılan Ali Suavi'nin önderliği altında gerçekleştirilen darbe girişiminin adıdır. Il. Abdülhamit'in Meclis-i Mebusan'ı tatil etmesinin ardından tekrar parlamentoyu hayata geçirmek ve hapiste bulunan V. Murat'ı tekrar tahta geçirmek amacıyla düzenlenmiştir. Olayda İngiliz ajanları ve bürokratları da önemli roller üstlenmişlerdir.
Nihayetinde 20 Mayıs 1878'de Ali Suavi'nin başında olduğu 250 kişilik bir grup Çırağan Sarayıına baskın düzenledi. Darbe girişimi başarısız oldu ve Abdülhamit'e sadık kuvvetler ayaklanmayı bastırdı. $\mathrm{Bu}$ arada ayaklanma esnasında darbeyi bastırmaya gelen Beşiktaş muhafızı Hasan Paşa'nın vurduğu bir sopa darbesiyle Ali Suavi olay yerinde öldü (Eraslan, 1996: 64). Ali Suâvi'nin yandaşlarından kırk ya da elli kişi öldürüldü ve hayatta kalanlar tutuklanarak yargılandılar. Bu başarısız darbe girişimi tarihe Çırağan Baskını/Vakıası olarak geçmiştir. Birçok devlet adamı ve yüksek rütbeli bürokrat arasında görevden alınma ve iç sürgün cezalarına neden oldu. Olay İngiliz Büyükelçisi Lord Layard ve sekreterinin yanı sıra Masonların da Ali Suavi'nin arkasında oldukları iddia edildi; ancak bu tür bir ilişki hiçbir zaman ispatlanamadı.

\subsection{Prens Sebahattin'in Darbe Girişimi}

Abdülhamit'in yeğeni olan Prens Sabahattin, babasının ölümünden dolayı dayısını sorumlu tutmakta ve ona karşı kin beslemekte idi. Bu yüzden II. Abdülhamit'e muhalif olanlarla işbirliğine gitmiş ve darbe girişimine kadar varan bir sürecin merkezinde yer almıştır. Nihayetinde Prens Sabahattin dönemin bazı simaları ile II. Abdülhamit'i tahtan indirmek için bir darbe girişiminde bulunmuş; ancak başarılı olamamıştır.

I. Jön Türk Kongresi'nde II. Abdülhamit'e darbe yapmak için destek bulamayan Prens Sabahattin, Arnavut dostları İsmail Kemal ve Recep Paşa ile darbe yapmaya karar vermişti. Malta'da yapılan ilk darbe planına göre, Trablusgarp Valisi Recep Paşa sultana karşı bir askeri darbe gerçekleştirmek üzere Selanik gibi önemli bir merkezi askeri kuvvetlerle ele geçirecek, bu yolla Avrupa'nın dikkati bu bölgeye ve olaylara çekilecek ve Padişah'a darbecilerin istekleri dayatılacaktı. Fakat bu plandan daha sonra vaz geçilmiş ve doğrudan İstanbul'da Padişaha darbe yapılması kararlaştııılmıştır. Plana göre, Recep Paşa'nın komuta ettiği bir piyade alayı ve iki batarya topçu birliği Trablusgarp'tan tatbikat bahanesi ile bindirilecek ve Sultana saldırmak için Çanakkale'ye getirilecekti. Tatbikat bahanesi ile getirilecek olmasının sebebi birliğin Çanakkale'deki askerler ve memurlar tarafından engelleme intimalinin olmasıydı. Daha sonra Recep Paşa'nın komuta ettiği askerler Çanakkale Boğazını kontrol altına alacak ve Ingilizlerin filosundan da destek istenecekti. Daha sonra askerler bir İngiliz ticaret gemisine bindirilecek, Yeşilköy ile surların arasında bir yerde karaya çıkarılacak ve İstanbulıdaki diğer birlikle birleşerek saray ele geçirilecekti. Darbe bütün ayrıntıları ile planlanmıştı; 
fakat daha sonra darbeciler arasında çıkan tartışmalar sonucunda Recep Paşa darbeciler arasından ayrılmış, böylece darbe eylem safhasına geçmeden sona ermiştir. Darbe girişiminin akim kalması nedeniyle Prens Sabahattin ve arkadaşları Paris'e dönmüşlerdir. Ancak faaliyete geçmese de bu darbe girişimi Prens Sabahattin'e yüklü bir faturaya mal olmuştur (Birecikli, 2012: 683-694).

\subsection{Rumeli Kalkışması}

II. Meşrutiyeti hayata geçirmeyi amaçlayan bu girişimim, genel özelliği itibariyle bir halk hareketi değil, askerî bir kalkışmadır. Bu kalkışmaya, ordunun hemen hepsi katılmamışsa da devletin en kritik sınırlarını koruyan III. Ordu'daki orta ve alt rütbeli subaylar ve bir kısım askeri birlikler, kalkışmayı yürüten ana kesimdir.

Hareketin başııca yöneticileri olan alt ve orta rütbeli mektepli subayların gizliliklerini riske sokan hafiyelerin sindirilmesi yoluyla planlarının ilk aşaması başlamıştır. $\mathrm{Bu}$ amaçla en etkili hafiyelerden Albay Nazım Bey saldırıya uğramış ama öldürülememiştir. 5 Temmuz'da Resne Garnizonu isyan ederek, 200 asker ve 20 kadar subay, bölgenin tabur komutanı olan Binbaşı Resneli Niyazi Bey'in emrinden firar edip dağa çıkmıştır (Ahmad, 2012: 16). Niyazi Bey ve adamları yanlarına sadece askerleri değil, sivil görevlileri de almışlardır. Niyazi Bey'in isyanından sonra, birçok düşük rütbeli subaydan başka, Hilmi Paşa'nın kurmay heyetinden Binbaşı Enver Bey de isyan hareketini destekleyip katılmıştır (Ahmad, 2012: 20).6 Temmuz'da ise, İttihat ve Terakki Cemiyeti, Manastır'da aktif rol almaya başlamış ve süreci etkin olarak yönlendirmiştir.

Askerî ve sivil desteği arkasına almayı başaran Itttihat ve Terakki Cemiyeti halk adına çektirdiği telgraflarla anayasanın yürürlüğe konmasını ve Mebusan Meclisi'nin toplantıya çağrıımasını istemiştir. Olumlu bir cevap alınamayınca Manastır merkezde top atışlarıyla meşrutiyet devrinin başlangıcı duyurulmuştur. Manastır ve Firzovik'teki bu olaylar, diğer Cemiyet merkezlerini de harekete geçirmiş, Yıldız Sarayı'na peş peşe telgraflar çekilmiştir. Nihayet, Serez'den gelen bir telgrafta gerekirse başka bir padişah adayının padişah olarak tanıtılacağından bahsedilmesi, Yıldız Sarayı'nda endişeye yol açmış ve Sarayın direnci düşmüştür. II. Abdülhamit, 23 Temmuz 1908'de Parlamento'nun toplanacağını duyurmuş ve Kanunu Esasi'nin tekrar yürürlüğe koyulması için emir vermiştir (Karal, 1988: 123). Sonuç olarak kalkışma istenen başarıyı elde etmiş ve Meşrutiyetin tekrar yürürlüğe girmesini sağlamıştır.

\subsection{Mart Kalkışması ve Hareket Ordusu'nun 1909 Darbesi}

31 Mart Kalkışması, bir grup askerin II. Meşrutiyete ve İttihat ve Terakki Cemiyetine karşı gerçekleştirdiği, önce askerî sebeplerle, daha sonra dinî, siyasi ve sosyal gerekçelerle genişlemiş bir darbe girişimidir. Alaylı subayların ordudan tasfiye edilmesini engellemek, mektepli subayları ordudan atmak, İttihat ve Terakki Cemiyeti'ni siyasal iktidardan uzaklaştırmak, şeriat usullerini hâkim kılmak gibi sebepler darbe girişiminin somut hedefleridir. Açıkça ifade etmek gerekirse darbeci askerler, meşrutiyetle sorunları olduklarından değil, İttihatçı politikalardan rahatsızlık duyduklarından böyle bir eyleme başvurmuşlardır. Kitleleri harekete geçirmek için, Itttihatçıların laik uygulamaları ve bazı dini hassasiyetlere karşı yeterince duyarlı davranmadıkları yönündeki toplumsal algı kullanılmış ve isyancıların sloganı “şeriat isteriz!" olmuştur (Ahmad, 2013: 33).

Olayların başlangıcı gazeteci Hasan Fehmi Beyin cenaze töreni olmuştur. 6 Nisan 1909'da İttihat ve Terakki Cemiyeti aleyhine yazılar yazan Ahrar yanlısı Arnavut asıllı Hasan Fehmi öldürülmüş ve katiller bulunamayınca Cemiyetin suikast gerçekleştirdiği kanısı kamuoyuna hâkim olmuştur. Bu yüzden Hasan Fehmi cinayeti 31 Mart Kalkışması'nın yakın sebebidir. Cenaze 8 Nisan 1909' da geniş katılımlı cenaze töreniyle kaldırılmış, ardından Cemiyet aleyhine büyük gösteriler düzenlenmiştir. 13 Nisan 1909'da da (31 Mart 1325 Rumi) askerler ayaklanmıştır.

13 Nisan'da (31 Mart) Taşkışla'daki 4. Avcı Taburu, Resneli Niyazi Bey'in yanında Meşrutiyet için dağa çıkan askeri birlikte yer almış olan Hamdi Çavuş önderliğinde ayaklanmıştır (Ahmad, 2013: 33). Askerler, subayları yakalayıp hapsederek harekete geçtikten sonra, onbaşı ve çavuşların komutasında "şeriat isteriz!" sesleriyle Ayasofya önlerine gitmişlerdir. Diğer askeri birliklerin, Ilımiye sınıfının alt derecesinden ulemanın ve medrese öğrencilerinin katılımıyla isyan büyümüştür. İsyancılar Meclise yani Sultanahmet'e yürümüşlerdir. Yolda rastladıkları mektepli subayları öldürmüşlerdir. Şikâyetlerini söylemek için Meclise geldiklerinde karşılarında muhalif mebusları bulmuşlardır; çünkü İttihatçı mebuslar o gün meclise gelmemişlerdir. Bu arada Meclis'e geldikleri zaman mebuslar kendilerini sükûnetle karşılamışlar ve taleplerini dinlemişlerdir. Neticede, Meclis onların taleplerini karşılamayı taahhüt etmiş ve isyancı askerleri bağışlamıştır. Talepleri yerine getirilen isyancılar Seyfiye ve İlmiye mensupları birlikte sevinç gösterilerinde bulunmuşlardır. Askerler affedildiğini öğrenip bu kez II. Abdülhamit'in yanına 
Yıldız Sarayı'na yürümüşler ve Abdülhamit de cama çıkarak onlara el sallayarak, dağılmalarını istemiştir (Ahmad, 2013: 33-34).

Kalkışma başarılı olmuş, isyancıların talepleri doğrultusunda yönetim kadroları yeniden belirlenmiş Hüseyin Hilmi Paşa istifa etmiş; Ahmet Tevfik Paşa sadrazamlığa getirilmiş ve Meclis tarafından şeriata uyma kararı alınmıştı. Böylece, İttihatçı asker ve sivil bürokratlar, özellikle başkentte ağır bir darbe aldıklarından güçlerini toplamak üzere Rumeli bölgesine çekilmişlerdi. Netice itibariyle muhalifleri bünyesinde toplayan Ahrar Fırkası'nın ve fırkanın lideri Prens Sabahattin'in İttihat ve Terakki Cemiyeti'ne karşı yürüttüğü bu kalkışma, daha sonradan bu fırkanın kontrolünden çıkmış ve kanlı bir harekete dönüşmüştü. İsyan sonucunda, mektepli subaylardan yirmisi, bir bakan ve iki de milletvekili öldürülmüştü (Ahmad, 2013: 33).Kalkışmadan3 gün sonra Meclis toplandı. Meclis mevcut durumu ve 31 Mart'ın statüsünü benimsiyorlardı. Olayı bir oldu-bitti olarak değerlendiriyorlar ve doğal sürece geçmeyi tercih ediyorlardı. Darbe girişimini bastırmak için Hareket Ordusu harekete geçti ve Yeşilköy de yığınak yaptı.

23 Nisan’ı 24 Nisan'a bağlayan Cuma günü gecesi Hareket Ordusu komutanı Mahmut Şevket Pasa İstanbul içlerine ilerleme emri verdi. İstanbul'a giren Hareket Ordusu birlikleri Taksim Kışlası ve Taşkışla'yı kuşattı. Hareket Ordusu askerleri, Taşkışla'da direnişle karşılaştı. Hareket Ordusu bu direnişi kırmak için Taşkışla'yı top ateşine tuttu. Nihayetinde Hareket Ordusu Taksim, Taşkışla ve Maçka kışlalarını işgal etti; İstanbul'daki bütün karakollar teslim alındı ve oralara Hareket Ordusu askerleri yerleştirildi. Son olarak Yıldız Sarayı kuşatması aşamasına geçildi. 27 Nisan'ı 28 Nisan'a bağlayan gece II. Abdülhamit tahttan indirildi ve beraberinde ailesi ve hizmetçilerinden oluşan toplam 28 kişi olduğu halde yanına aldığı birkaç şahsi eşyasıyla birlikte Selanik'e sürgüne gönderildi (Tursun, 2013: 74-5). Kurulan divanıharpta darbeye adı karışanlar yargılandı. Öncelikli olarak darbeye karışan askerlerden bazıları, en başta Hamdi Çavuş olmak üzere, asıldı; diğer askerler de yol işçiliği ile cezalandırıldı. İsyana ismi karışan siviller de yargılandı. Volkan gazetesi sahibi Derviş Vahdeti asılırken diğerleri de hapis ve sürgün cezalarına çarptırıldı.

Sonuçta darbe girişimi başarısız olmuş, hatta var olan durumu daha kötü bir hale getirmiştir. Çünkü askerin ve Cemiyetin siyasal iktidar üzerindeki etkisi daha fazla artmıştır. Mahmut Şevket Paşa 31 Mart sonrası siyasi tabloya damgasını vurmuş ve 3 yıl sürecek olağanüstü hal dönemi başlamıştır.

\subsection{Ocak 1913 Askeri Darbesi (Bâbıâli Baskını)}

Babıâli Baskını, 23 Ocak 1913 günü Enver ve Talat Paşaların başını çektiği bir grup İttihatçı tarafından Sadaret binası olan Babıâli'nin basılmasıyla gerçekleştirilen askerî darbenin adıdır. Kamil Paşa kabinesinden rahatsız olan ve doğrudan iktidarı devralmak isteyen İttihat ve Terakki Cemiyeti üyeleri, Kâmil Paşa hükümetine karşı çok önceden beri darbe planları yapıyorlardı. Nihayetinde 23 Ocak 1913 tarihinde hükümete karşı Bâbıâli Baskını olarak da bilinen askeri darbe meydana geldi.

Enver Paşa, Talat Paşa ve Yakup Cemil önderliğindeki İttihatçı bir grup Osmanlı hükümet binalarına ve Bâb-ı Âlî́ye bir baskın yapmış ve Kamil Paşa kabinesi toplantıdayken kendilerine karşı koymaya çalışan Sadaret Yaveri Ohrili Nafiz Bey, Harbiye Nazırının yaveri Kıbrıslı Tevfik Bey, Komiser Celal Bey'i vurarak öldürmüştür. Silah sesleri üzerine kabine üyeleri dağılmıştır. Aynı zamanda Harbiye Nazırı Nazım Bey de olanları anlamak için çıktığı anda balkonda vurularak öldürülmüştür (Karal, 1988: 214). Ardından Enver Paşa Kâmil Paşa'nın odasına girerek silah zoru ile istifasını yazdırmış; istifa mektubunu alan Enver Paşa mektubu saraya bizzat götürmüştü. Kâmil Paşa'nın istifası V. Mehmet (Sultan Reşat) tarafından aynı gün onaylanmış ve İttihat ve Terakki'nin baskısıyla sadrazamlığa Mahmut Şevket Paşa getirilmiştir.

Askeri darbe sonrasında hep denetleme iktidarı İttihat ve Terakki Cemiyeti artık doğrudan iktidar olmuştur. Mahmut Şevket Paşa, 23 Ocak 1913'te Sadareti ve Harbiye Nezareti'ni üstlenmiştir. Sadaret Mahmut Şevket Paşa'nın hal ve hareketlerinde, özellikle de muhaliflere karşı tutumunda değişikliğe sebep olmuştur. Daha önce muhalefete, her türlü eleştiriye kapalı olan, daha önce kendisine karşı en ufak bir muhalif tutum sergileyenlerin kafasında asasını parçalayan Paşa, sadaretten sonra beklenenin aksine İttihat ve Terakki muhaliflerine karşı ı ımlı bir tutum sergilemiştir. Nihayetinde 11 Haziran 1913'te gerçekleşen bir suikastla hayatını kaybetmiştir. Böylece arkasında halk desteği yok denecek kadar az olan Itttihat ve Terakki Cemiyeti'nin artık diktatörce yönetimi başlamış oldu. İttihatçılar ulus devlet kurma projelerine hız verdiler, Turancı hayallerle Osmanlı Devleti'ni Birinci Dünya Savaşı'na soktular. 


\subsection{Haziran 1913 Darbe Girişimi ve Mahmut Şevket Paşa Suikastı}

Mahmut Şevket Paşa Osmanlı Devleti'nin son yıllarında önemli siyasi otoritelerinden birisi olmuştur. Osmanlı Ordusu'na uzun zaman hizmet etmiş ve Ocak 1913 Askeri Darbesi sonrasında Itttihat ve Terakki Cemiyeti'nin desteğiyle Sadrazamlığa ve Harbiye Nazırlığı'na atanmıştır. Balkan Savaşlarının en şiddetli koşullarında Sadrazam ve Harbiye Nazırı olarak görev yapan Mahmut Şevket Paşa, 11 Haziran 1913'te İstanbul Bayezid'de suikasta kurban gitmiştir. Mahmut Şevket Paşa'nın siyasal bir suikastla öldürülmesi adi bir vakı değildir. Hazırlanışı ve hedefleri bağlamında daha ayrıntılı bir eylem tarzıdır (Akşin, 1998: 235). Aslında amaç sadece bir suikast değil Babıali Baskını tarzı bir darbe girişimidir. Suikast darbenin bir parçasıdır. Cemiyet, suikastın yapılmasını engelleyememiş ya da engellememiş, fakat darbeyi engellemiştir.

"Babıali Baskını"nda öldürülen Harbiye Nazırı Nazım Paşa'nın mensup olduğu "Halaskar Zabitan" grubu darbenin planlayıcısıdır. Halaskaran Zabitan'ın öncülüğünde Kürt Şerif Paşa, Gümülcineli İsmail, Müdür Muhib, Miralay Fuad, Yüzbaşı Kazım, Pertev Tevfik, Kemal Midhat Bey'lerin başını çektiği bir komite littihat ve Terakki Cemiyeti'ni devirmek, Prens Sebahattin'i başa geçirmek için darbe yapmak düşüncesi etrafında bir araya geldiler. Nihayetinde 20 kişiden ibaret olan bir darbe ekibi oluşturuldu ve darbe planı yapıldı. Ancak darbe kötü planlanmıştı. Suikast belki iyi planlanmıştı; ama ilerleyen devreler acemice ve çok kötü planlanmıştı. Uygulanma imkânı yoktu. Önce planlanan suikastlar yapılacak, kabine üyeleri öldürülecekti. Mahmut Şevket Paşa, Talat, Enver Cemal ve diğer ittihatçılardan oluşan bütün kabine ve İttihat Terakki Cemiyeti'nin bütün Merkezi Umumi üyeleri öldürülecekti (Yalçın, 2000: 265). Ardından da halkın desteğini almak için sokak gösterileri düzenlenecekti. Darbeye halk desteğinin sağlanması için Emanuel Karasu ve Nesim Rosu'nun da öldürecekler listesinde yer almaktaydı Bunların Yahudi ve Ermeni olmaları darbenin Cemiyete karşı değil de bir Yahudi temizleyiciliği havası doğurması içindi (Yalçın, 2000: 265). Bu arada askerle saray kuşatılıp Sultan Reşat'la görüşülecek ve darbeye sarayın desteği sağlanacaktı.

29 Mayıs 1329 (11 Haziran 1913) perşembe günü suikast için seçildi. Bakanlar kurulu toplantısı çıkışı Mahmut Şevket Paşa'nın konvoyuna saldırıldı. Mahmut Şevket Paşa ve yaveri Bahriye Mülazımı İbrahim Bey başından aldığı kurşun yaralarıyla hayatını kaybettiler). Suikastın hemen ertesi günü (12 Haziran 1913) yabancı ülke temsilcilerinin de çağrıldığı, 150 bin kişinin katıldığı muhteşem bir cenaze töreni düzenlendi (Aydemir, 1993: 398).

Hükümet ani bir refleksle darbecilerin üzerine gitti ve suikastı gerçekleştirenlerin çoğunu yakaladı. Darbenin beyin takımı yurt dışına kaçtı. Kurulan divanıharpta yargılama süreci kısa tutuldu ve hızlı karar verildi. Divanıharp, 22 Haziran 1913 günü kararını açıkladı ve 12'si gıyabında olmak üzere 24 kişi hakkında idam, 2 kişi için müebbet kalebentlik cezası, 3 kişi için 15 sene müddetle kürek cezası verdi. İdam hükümlülerinin infazı hemen yerine getirilmiş ve 12 kişi Beyazıt Meydanı'nda asılmıştır.

Darbe girişiminin arkasında Halaskârân-ı Zabitan Grubu olduğu kanaatine varılmıştır. Halaskârân-ı Zabitan Grubu ve diğer gruplar bu olay sonrasında çözülme sürecine girmişler bununla birlikte İttihat ve Terakki Cemiyeti, yaşanan bu suikastı kendisi için fırsat haline getirme yolunda bazı adımları atarak gücünü ve iktidarını kuvvetlendirmiştir. Sonuç olarak Mahmut Şevket Paşa'nın öldürülmesi ve Haziran 1913 Darbe girişimi Osmanlı siyasetini kısa süreli bir kaosa sürüklemiş ve bu ortamdan en kârlı çıkan taraf İttihat ve Terakki Cemiyeti olmuştur. Birinci'ye göre; İttihat ve Terakki, bu olay sonrasında hem Mahmut Şevket Paşa'dan hem de siyasal rakiplerinden kurtulmak gibi çifte bir kazanç elde etmiştir (Birinci, 1990: 215).

\section{Cumhuriyet Döneminde Askerin Siyasi Rejimin Işleyişine Müdahaleleri}

\subsection{Mayıs 1960 Darbesi}

Demokrat Parti'nin (DP) 1950, 1954 ve 1957 seçimlerini kazanması gerek muhalif çevrelerde gerekse askeri kanatta huzursuzluklar yaratmıştı. Nihayetinde bu huzursuzluk ülkeyi 1960 darbesine götürdü.

Demokrat Parti'ye yönelik ilk darbeci örgütlenme 1955 yılında ortaya çıktı. DP iktidarından 5 yıl sonra İstanbul'da subay rütbesindeki askerlerden Dündar Seyhan ve Orhan Kabibay ilk cunta örgütlenmesini kurdu. Bu gruba Faruk Güventürk, Ahmet Yıldız, Suphi Gürsoytrak, Orhan Erkanlı, Necati Ünsalan gibi subaylar da katıldı. İstanbul yapılanmasındaki ekip, Binbaşı Samet Kuşçu'nun nüfuzundan yararlanmak için 1957'de onunla iletişime geçti. Darbeciler, 27 Ekim 1957 seçimiyle DP'nin iktidarı kaybetmesini umuyordu; ancak bu gerçekleşmeyince, artık seçimle uzaklaştıılamayacağı kanısını doğurduğu için darbe için düğmeye basıldı. Samet Kuşçu da hükümete cunta yapılanmasıyla ihbar mektubu yazınca soruşturma 
başlatıldı. Üç dört gün içinde 9 subay tevkif edildi. Cumhuriyet tarihinde ilk defa böylesine tutuklamalar yapılmıştı. 1957'de ortaya çıkan bu darbeci örgütlenme "9 Subay Olayı" adlandırımıştır. Bu olay sonrasında yapılan yargılamalarda tutuklular beraat ettirildi. Bu durum darbeci ekibin darbe planı yapma konusundaki cesareti arttırdı ve şartların olgunlaşması beklenmeye başlandı.

1959 ve 1960 yıllarında askeriye içerisinde darbe hazırlıkları hızla devam ediyordu. Meclis'te muhalefete soruşturma açılmış ve Demokrat Pati tarafından soruşturma komisyonu kurulmuştu (Belge, 2012: 626). Bu olaylar sırasında darbe yapılacağı konusunda birçok haber ve bilgi Adnan Menderes'e ulaşıyordu. Ancak Menderes darbeye ihtimal vermiyordu. Bunun nedeni ise Menderes'in Genelkurmay Başkanı Rüştü Erdelhun Paşa'ya güvenmesiydi (Gürsoy, 2012: 8). Ancak bu güveni boşa çıktı ve darbe 27 Mayıs 1960'da gerçekleşti. DP'liler tutuklanarak Yassıada'ya gönderildi ve askeri yargıçlar tarafından yargılandılar. Yargılamalar sonucu ne asıdır ki bir ülkenin Başbakanını ve iki bakanını astığına şahit olundu.

Siyasal iktidarın sahibi DP'yi darbe yoluyla devirmek gibi ortak paydada sorunsuz bir biçimde bir araya gelen subay grupları darbe sonrasında karşı karşıya geldiler ve iki grup ortaya çıktı. Bunlardan birincisi darbeyi gerçekleştiren ve ideolojik yönden homojen bir yapıya sahip olmayan subayların oluşturduğu Milli Birlik Komitesi olup, müdahale sonrası ilk bir yıl içerisinde fikirsel anlaşmazlıklar yüzünden kendi içinde bir tasfiyeye gittikten sonra yeni devlete dair bir takım temel düzenlemelere öncülük eden bir görüntü sergilemiştir. Silahlı kuvvetler personeli ve üniversiteler bünyesinde girişilmesi planlanan revizyon, yeni anayasa yapımı ve yönetimin olabildiğince kısa bir süre içerisinde düzenlenecek seçimler aracılığıyla sivil idareye teslim edilmesi düşüncesi komitenin genel eğiliminin karakteristiğini sunan unsurlar olarak karşımıza çıkmıştır. Milli Birlik Komitesi'ne rakip olarak değerlendirilebilecek ve ordu içerisinde çok kapsamlı bir örgütlenmeye giderek bilhassa Yassıada yargılamalarıyla birlikte ilk güçlü mesajını veren yapılanma ise Silahlı Kuvvetler Birliği olmuştur (Toker, 1991: 26). Özellikle devrik Demokrat Parti iktidarı ve onun temsil ettiği zihniyet dünyasına karşı son derece katı ve tavizsiz tutumlarıyla bilinen Silahlı Kuvvetler Birliği, 1962'den sonra daha da radikal bir tutum izlemiş, başını albayların çektiği cunta yapılanmalarıyla kendisinden söz ettirmiştir. Cumhuriyetin kurucu felsefesinin ışığında 27 Mayıs'ın öngördüğü reformları yerleşik kılıp, düzeni rayına oturtana kadar siyaset mekanizmasının devre dışı kalmasını savunan birlik içerisindeki albaylar grubu, 1962 ve 1963'te Talat Aydemir öncülüğünde iki adet başarısız darbe girişimine daha imza atmışlardır.

\subsection{Talat Aydemir Darbe Girişimleri}

\subsubsection{2 Şubat 1962 Darbe Girişimi}

Talat Aydemir'e göre 27 Mayıs darbesi hedefine ulaşmamış olması, 27 Mayıs 1960'tan önceki durumda olduğu gibi halkın 2 gruba ayrılmış olması ve "Milli Birlik" ruhunun yaratılamamış olması, parlamento içinde bir kısım siyasilerin maksatlı tutumları ile silahlı kuvvetlerin halk ile karşı karşıya getirilmiş olması ve seçim sonrası, siyasi ortamda istikrarlı ve dinamik bir hükümet kurulmayışı yüzünden ülkenin asıl temel davası olan reformların ele alınmayış olması bir askeri müdahaleyi gerekli kılmaktadır (Demir, 2006: 161-162). Ayrıca Talat Aydemir, 1961 yılının Ekim ayında yapılan genel seçim sonuçlarını karşı devrim olarak nitelemiş ve karacı albaylardan oluşan bir cunta oluşturulmuştu. Karacılardan oluşan albaylar cuntası gerektiğinde siyasal rejime müdahale edecektir (Börklüoğlu, 2017: 25).

Talat Aydemir'in örgütlenmesinden haberdar olan Genelkurmay Başkanı Cevdet Sunay, 19 Ocak 1962 tarihinde Genelkurmay karargâhında komutanlarla yaptığı toplantıda askeri müdahale heveslerinden onları vaz geçirmeye çalıştı. Ancak toplantıda, karacı albaylar, başta Talat Aydemir olmak üzere, askeri müdahalenin gerekliliğini savunmuşlardır. Bu süreçte, İsmet İnönü de ordu içindeki kıpırdanmaların farkında olmuş; fakat sert bir şekilde uyarmaktansa yatıştırma yolunu denemiştir. İnönü'nün sağduyu çağrısı cevap bulmuş, özellikle Hava Kuvvetleri, Türk Silahlı Kuvvetleri adına yapılacak bir eylemin Hava Kuvvetleri olmaksızın gerçekleştirilmesi gerektiğini iletmişlerdir (Çakmak, 2015: 40)

Talat Aydemir ve arkadaşlarının 20-21 Şubat gecesi harekete geçecekleri söylentisi yayılmaya başlayınca Ankara'daki ordu çevrelerinde hareketlilik olmuş, Etimesgut Zırhlı Birlikler Okulu Birinci Zırhlı Tümen Tank Taburu'nda bazı subaylar birliklerini alarma geçirmişlerdi. 229. Piyade alayı ve muhafız alayı süvari grubu da alarma geçince darbe başlıyor görüntüsü ortay çıktı. Sabaha karşı Talat Aydemir'in olup bitenlerden habersiz olduğunu öğrenen Kurmay Binbaşı Bahtiyar Yalta, "Bir yanlışlık var" diyerek alarmı kaldırmıştır. Talat Aydemir ve arkadaşları, gece gelişen olayları kendilerine karşı bir tuzak olarak algılamış zaman 
kaybetmeden darbe programlarını hayata geçirmeye yönelmişlerdir. Darbe için alarmı 21/22 Şubat 1962 akşamında verdiler. Harekâtın parolası "halaskar", işareti ise "fedailer" olarak belirlendi. Alarmdan haberdar olan Genelkurmay Başkanlığı da karşı tedbirlerini aldı. Genelkurmay'ın etrafı tanklarla muhafaza altına alındı; Meclis Muhafız Taburu Meclisin etrafını çevirdi. Orduda ikilik baş göstermiş oldu; kimi birlikler Aydemir yanlısı kimileri ise genelkurmay ve hükümet yanlısı bir duruş sergiliyorlardı (Çakmak, 2015:43). Hava kuvvetlerinin ve ordunun üst kademesinin desteği olmadan darbenin başarılı olması mümkün değildi. Nitekim darbenin bastırılması hiç zor olmayacaktı. Talat Aydemir de bunun farkında olduğu için tereddüt gösteriyordu. Aydemir, harekât yapıldığında meydana gelebilecek olayları dikkate alarak harekâtı durdurma kararı aldı. 22 Şubat'ı 23 Şubat'a bağlayan gece İnönü-Sunay ekibi ile Aydemir ekibi pazarlık sonucu darbeden vazgeçildi; buna karşılık darbeci ekip affedildi

Başbakan İsmet İnönü'nün, Talat Aydemir'in serbest bırakıldığı 26 Şubat 1962 günü, darbe girişimini değerlendirdiği konuşmasında Harp Okulu öğrencilerinin aldatıldığını belirtmesi üzerine yeni olaylar çıkmış ve bazı öğrenciler üzerinde "Harbiyeli Aldanmaz" sözleri yazılı bir çelengi Taksim'deki Atatürk Anıtı'na koydular. Bu sözler, daha sonra 21 Mayıs'ın parolası olarak kullanılacaktır. Bu gelişmeler sonucu Harbiyeli öğrenciler hakkında soruşturma açılarak ve mahkemeye verilmişlerdir (Demir, 2006: 163-164).

\subsubsection{Mayıs 1963 Darbe Girişimi}

Ordu içindeki kaynaşma, 22 Şubat darbe girişiminin bastırılmasından sonra tamamen bitmemişti. Dönemin kuvvet komutanları İnönü tarafından kurulacak bir hükümetin ancak ordu içindeki kaynaşmayı denetim altında tutabileceğini düşünüyorlardı. O sıralar hükümetten çekilen İnönü'yü tekrar başbakan olması için ikna ettiler. Fakat İnönü hükümet üyelerinin uyum içinde çalışmadığını gören ordu içindeki darbe heveslileri ile emekli olmuş eylemci subaylar tekrardan umutlanmışlardı (Çakmak, 2015: 47).

21 Mayıs'a giden süreç içinde, 22 Şubatçılar kendilerini iki sorunla karşı karşıya bulmuşlardı. Birincisi, siyaset alanında işlevleri ne olacaktı; ikincisi ise, kendilerine emeklilik hakkı tanınmadan ordudan atılan arkadaşlarına ne şekilde yardım edeceklerdi? 22 Şubatçılar, yapacakları darbe ile arkadaşlarını tekrar aktif göreve alacaklar, siyaset alanına da doğrudan, yani darbe sonrası kuracakları bir siyasal partiyle gireceklerdi. Bu yüzden $14^{\prime}$ lerden Orhan Kabibay
Grubu'nun Atatürkçü Parti kurmak için girişime geçmişti. Bu arada 22 Şubatçılar yapacakları harekâtı "Kemalizm Doktrini" üzerine oturtmak istiyorlardı. Onlara göre Kemalizm, kişisel hâkimiyetin yerine milli hâkimiyetin sağlanması idi (Demir, 2006: 165)

22 Şubatçıların oluşturduğu Türk Silahlı Kuvvetler Birliği'nin fikir karargâhı, 1963 yılının Mart ayında düzenlenen toplantıda kuvvetlerin son durumu gözden geçirildi. Fethi Gürcan'ın bizzat yönlendirdiği Tank Okulu'ndaki Tank ve Süvari subaylarının kursu, Nisan'ın ilk haftalarında biteceği için 20 Mart-20 Nisan tarihleri arasında darbe tarihi belirlenecekti. Darbe girişimi, 20 Mart 1963'te emniyet istihbaratı tarafından öğrenilince eylem ertelendi. 15 Mayıs 1963 tarihinde, Aydemir ve arkadaşları yaptıkları toplantıda darbe girişiminin tarihini bu kez 20-21 Mayıs olarak belirlediler. Aydemir'in ikinci darbe girişimini Alparslan Türkeş öğrenmiş ve bu bilgiyi 20 Mayıs 1963'te başbakan İnönü'ye iletmişse de İnönü, Aydemir ile taraftarlarının yeni bir kalkışma yapacaklarına ihtimal vermemiştir. Ancak İnönü'nün Türkeş'in ihbarına verdiği bu cevaptan birkaç saat sonra Talat Aydemir, harekât için alarm vermiş ve harekâtı başlatmıştır (Çakmak, 2015: 51).

Radyo ihtilalciler tarafından ele geçirildi ve intilal bildirisinde Türk Silahlı Kuvvetleri'nin ülke yönetimine el koyduğu söyleniyordu. Aslında bütün ihtilal kuvveti, 22 Şubat emeklisi birkaç subay, bir grup Harp Okulu öğrencisi ve radyoevi önündeki üç tanktan ibaretti. Haberi duyan 28. Tümen Komutanı Yarbay Ali Elverdi yanında aldığı iki erle radyo binasını basarak, anonsları yapan ihtilalci üsteğmeni tutukladı ve spiker koltuğuna oturarak darbeyi yalanladı. Elverdi, birliklere hitaben de hemen kışlalarına dönmelerini ve ikinci bir emri beklemelerini söyledi (Önal, 2017: 21). Ankara Radyosu Talat Aydemir yanlısı birlikler tarafından ikinci defa işgal edildi. Bu defa, eylemci subaylar tarafından Yarbay Ali Elverdi tutuklandı ve radyodan Ihtilal Genel Karargâhı'nın 2 numaralı tebliği yine okundu. Bunun üzerine hükümet tarafından, 22 Şubat'ta olduğu gibi, Etimesgut verici istasyonu ile radyoevinin irtibatı kesildi ve radyo yayını susturuldu. Radyo yayınının susması üzerine halk sokağa çıkmaya başladı. Ortada bir belirsizlik durumu oluşmuştu. Bu arada sabaha karşı Hava kuvvetleri, belirsiz tutumunu bir kenara bırakarak tarafını belirleyerek hükümetten yana tavır aldı. Ankara semalarında Hava Kuvvetlerinin uçakları görülmeye başlandı. Bunun üzerine Radyo tekrar yayına geçi ve Genelkurmay başkanı Cevdet Sunay'ın ültimatomu okundu. Ültimatomdan sonra İhtilal Genel Karargâhı olan Harp Okulu karıştı ve Aydemir yanlısı birliklerde 
çözülmeler başladı. Havacıların havadan müdahalesi Aydemir'in bu ikinci darbe girişiminin de sonunu getirmiştir. Aydemir ve taraftarları tutuklanmıştır.

Darbe girişiminin batırımasından sonra Bakanlar Kurulu, Ankara, İstanbul ve İzmir'de bir ay süreli sıkıyönetim ilan etti. Ankara Sıkı Yönetim Komutanlığı, sanıklar için üç ayrı mahkeme kurmuş ve yargılamaları gerçekleştirmiştir. 1 Numaralı Sıkı Yönetim Mahkemesi darbe girişiminin asıl sanıkları olan Aydemir ve arkadaşlarını, 2 Numaralı Sıkı Yönetim Mahkemesi Harp Okulu öğrencilerini, 3 Numaralı Sıkı Yönetim Mahkemesi ise darbe girişimim lehine teşebbüste bulunanları yargılamıştır (Demir;168). Yargılamalar 6 Eylül 1963 tarihinde sona ermiş̧tir. Yargılama sonucunda 7 idam, 29 müebbet hapis ve 45 beraat kararı çıkmıştır (Önal; 22). Sanıklar temyize başvurmuşlar; fakat Askeri Yargıtay, idama mahkûm olan 7 kişiden dördünün cezasını onarken, diğer üçünün idam cezasını bozmuştur. Harp Okulu öğrencileri okuldan atılmış, Talat Aydemir ve arkadaşları idam edilmişlerdir (Çakmak, 2015: 55).

\subsection{Mart Muhtırası}

12 Mart 1971 tarihinde gerçekleşen muhtıra Türk siyasi hayatında, siyasi krizlerden birine işaret etmektedir. Siyasal şiddetin yayılımı, siyasal istikrarsızlık, komünist örgütlenmeler ve bunun orduya yansımasından sonra Genelkurmay Başkanı Memduh Tağmaç, Kara Kuvvetleri Komutanı Faruk Gürler, Deniz Kuvvetleri Komutanı Celal Eyiceoğlu ve Hava Kuvvetleri Komutanı Muhsin Batur'un imzasıyla Cumhurbaşkanı Cevdet Sunay'a bir muhtıra verilerek hükümet istifaya zorlandı.

Muhtıra, 12 Mart 1971 günü saat 13.00 sıralarında TRT radyolarından duyuruldu. Muhtıra metninde ülkenin içinde bulunduğu durumdan bahsedildikten sonra silahlı kuvvetlerin bu durumdan duyduğu rahatsızlık ve endişe dile getirilerek "Bu husus süratle tahakkuk ettirilemediği takdirde, Türk Silahlı Kuvvetleri, kanunların kendisine vermiş olduğu Türkiye Cumhuriyeti'ni korumak ve kollamak görevini yerine getirerek idareyi doğrudan doğruya üzerine almaya kararlıdır" ifadesiyle hükümeti istifaya davet etmiştir (Kayalı, 1994: 48). Bu arada Muhtıra Cumhurbaşkanlığı, Cumhuriyet Senatosu Başkanlığı ve Millet Meclisi Başkanlığı́na da gönderildi. Muhtıra sahipleri radyoda okuttukları metnin Meclis Genel Kurulu'nda da okunmasını istediler. Yapılan itirazlara rağmen Muhtıra Meclisten okundu ve Başbakan Süleyman Demirel bu olaydan sonra istifasını verdi. Bunun üzerine Cumhurbaşkanı Cevdet Sunay, tarafsız ve partiler üstü bir hükümet kurulması için parti liderleriyle bir araya geldi ve Nihat Erim ismi üzerinde anlaşmaya varıldı. Nihayetinde Nihat Erim 26 Mart 1971'de kabinesini açıklayarak I. Erim Hükümeti'ni kamuoyuna duyurdu.

Sonuç olarak 12 Mart Muhtırası askerin parlamenter rejime müdahalelerinden birisidir ve başarılı olmuştur. Ordu parlamentoyu ve cumhurbaşkanını saf dışı bırakmamış, doğrudan olmasa bile sivil idareye dolaylı olarak müdahale etmiştir. Siyasal rejimin işleyişini kesintiye uğratmasının ve demokrasiye verdiği zararın yanı sıra sol ideolojiye ve örgütlere yönelik bir darbe niteliği taşımaktadır. Ordu, ülkede asayişi sağlayamadığı gerekçesiyle Demirel hükümetini istifaya zorlamış, yerine "partiler üstü" hükümet kurdurtarak beklentilerini karşılayacak bir siyasal yapılanmaya ülke siyasetini zorlamıştır (Akıncı, 2017, 55-72).

\subsection{Eylül 1980 Askeri Darbesi}

12 Eylül 1980 darbesi, Türk siyasi hayatında ciddi bir dönüm noktası olmuştur. Bu tarihte ilk defa Türk Silahlı Kuvvetleri bütün halinde doğrudan siyasal rejime müdahale etmiştir. 12 Mart Muhtırası ile yapılan dolaylı müdahale 12 Eylül ile doğrudan müdahaleye dönüşmüştür. Üstelik hiçbir direnişle karşılaşmamıştır.

12 Eylül darbesinin nedenlerine göz atıldığında öncelikli olarak temel nedenin yetmişli yıllardaki sosyal, ekonomik, kültürel ve siyasi kaosun sonucunda olduğu görülebilir. Yetmişli yılların Türk siyasi hayatına egemen olan bölünmüşlük, partiler arasında gerçekleştirilemeyen işbirliği ve diyalog noksanlığı, sosyal ve ekonomik gelişmelerin siyasi sitem üzerinde yarattığı baskılar ve karşılanamayan taleplerin sebep olduğu arayışlar, sorun çözemeyen siyasi kurumlar, uluslararası alanda gözlemlenen bölgesel güvenlik sorunlarının dünya sistemi için taşıdığı önemi yeteri derecede değerlendirememesi ve buna uygun davranışta bulunamaması gibi hususlar 12 Eylülün arka planını süsleyen gelişmeler olarak öne çıkmaktadır (Dursun, 2004: 7). Bunlar arasında siyasi görüşlerin sağ ve sol olarak gruplaşmaları, bu gruplar arasında meydana gelen karşııkı saldırılar ve ekonomik alanda yaşanan olumsuzluklar ülkeyi darbe sürecine götüren nedenlerdir.

Türk siyasal hayatında kara bir leke olarak kabul edilen 12 Eylül darbesi, 12 Eylül sabaha karşı Kenan Evren başkanlığındaki beş üst düzey generalden oluşan Milli Güvenlik Konseyi (MGK) tarafından yönetildi ve başarılı oldu. Yüzbinlerce insan gözaltına alındı ve tutuklandı. Binlerce insana uygulanan uluslararası seyahat yasaklarına rağmen 30.000 kişi yurtdışına siyasi 
mülteci olarak kaçtı. Yaklaşık 14 bin kişi vatandaşlıkları iptal edildi; binlerce kişi sivil hizmetten kovuldu ve filmler, kitaplar, gazeteler ve dergiler sansürlendi ve tüm sosyal topluluk grupları kapatıldı. Ülkenin darbeden kaynaklanan ekonomik kaybının yaklaşık 50,4 milyar dolar olduğu tahmin edilmektedir.

Türk Silahlı Kuvvetleri'nin demokratik yollarla seçilmiş hükümeti üçüncü kez ele geçirdiği ve binlerce kişinin yasadışı bir şekilde gözaltına alındığı ve hatta işkenceye maruz kaldığı bir olağanüstü hâlin ilan edildiği bir dönemdir. Liderler sorgulanırken, yargılanırken ve hapsedilirken siyasi partiler kapatıldı ve birçok yasak getirildi. Askeri mahkemede 230.000 'den fazla insan yargılanmış ve bunların 517'si ölüm cezası alırken, 14.000 kişinin vatandaşlığı iptal edilmiştir. Raporlara göre, sorgulama sırasında işkence sonucu 171 kişi öldü, 30 bin kişi de işten atılmıştır. Buna ek olarak, bir milyondan fazla insan kara listeye alınmış ve solcu, sağcı, milliyetçi, muhafazakâr ve benzeri bir ideolojik örgüt üyesi olma suçundan 98 bin 404 kişi yargılanmıştır. Kenan Evren başkanlığındaki Milli Güvenlik Kurulu, 1983 yılına kadar hükümete ilişkin tüm kritik kararları almış ve sokağa çıkma yasağı ile ülkede sıkıyönetim uygulamıştır (Yetkin, 2006: 97). Milli Güvenlik Kurulu, atadığı insanlardan oluşan bir kurucu meclis kuruldu. Anayasanın muğlak ifadelerine yer veren son rötuşları bu Parlamento tarafından yapıldı. Evren, tıpkı bir politikacı gibi, ülke çapında bir turneye çıktı ve halkı Anayasaya oy verme zorladı. Anayasa referandumda reddedilirse, olayların bir önceki dönemlere döneceğine dair mesaj vermeye çalıştı. Anayasa, 7 Kasım 1982'de gerçekleşen referandumda oyların yüzde 92'siyle onaylandı. Darbe öncesinde terörden korkan insanlar darbeyi benimsemişlerdi. Böylece Evren cumhurbaşkanı oldu ve Anayasa cuntayı yasallaştırdı. Bir devleti, özellikle de ekonomiyi yönetmenin zorluklarıyla uğraşırken, genellikle cuntalar sahneden çekilir ve siyaseti sivillere bırakır. Bu durumda da aynıydı. Cunta, siyasal partilerin yeniden kurulmasına izin verdi.

Sonuç olarak 1960'dan sonra öyle ya da böyle her on yılda bir parlamenter demokrasinin işleyişine müdahale edilmesi gelenek haline gelmiş ve demokratik sitemden geriye dönüşler yaşanmıştır. Onar yıllık periyotlarla demokratik sistemden geriye dönüşlerin yaşanması demokrasinin yeteri kadar kurumsallaşmadığını, demokratik kurum ve yöntemlerin toplum kesimlerince yeteri derecede tasvip ve takdir edilmediğini ortaya koymaktadır.

\subsection{8 Şubat 1997 MGK Bildirisi: Post-modern Darbe}

Siyasal literatüre "post modern darbe" olarak geçen 28 Şubat 1997 tarihli MGK toplantısı, Türkiye'de toplumun laik-dinci diye kutuplaştığı, görsel ve yazılı medyada sansasyonel başlıkların atıldığı, korku ve gerilimin hâkim olduğu bir ortamda gerçekleşti. 28 Şubat'ın mimarlarının gözünde "demokrasiye balans ayarı" yapılıp laik düzen korunurken seçilmiş RefahYol hükümetinin düşürülmesi ve sonrasında özellikle başörtülü gençlerin eğitim hakkının engellenmesiyle sembolleşen mağduriyetler dönemi başladı (Öcal, 2009: 4).

Post-modern Darbe'nin nedenleri olarak Başbakan Necmettin Erbakan'ın 1994 yerel seçimleri sonrasında sarf ettiği "Refah Partisi iktidara gelecek, adil düzen kurulacak. Sorun ne? Geçiş dönemi sert mi olacak, yumuşak mı olacak? Tatı ı ı olacak, kanlı mı olacak?" sözünün şeriatçı söylem olarak değerlendirilmesi, yine Erbakan'ın Libya gezisi sonrası Kaddafi'nin cüretkâr sözleri, Erbakan'ın tarikat liderlerine verdiği iftar yemeği, Refah Partili Sincan Belediyesi'nin düzenlediği Kudüs Gecesi gibi nedenler öne sürüldü. Post-modern darbenin ilk belirtilerini 4 Şubat'ta Sincan'da askeri konvoyun geçişi duyurdu. 15 tank ve 20 zırhlı araçtan oluşan konvoyun geçidi askerin darbe uyarısı olarak algılandı. Dönemin Genelkurmay İkinci Başkanı Çevik Bir, Sincan'daki askeri konvoyun geçidi "demokrasiye balans ayarı" olarak nitelendirdiği çok konuşuldu (Öcal, 2009: 4). Nihayetinde 28 Şubat 1997'de dokuz saat süren Milli Güvenlik Kurulu toplantısından, tarihe "post-modern darbe" olarak geçecek 18 maddelik bildiri çıktı. Bildiride hükümet laiklik konusunda sert bir şekilde uyarılıyor ve laikliğin teminatı için kanunların uygulanması ve sıralanan önlemlerin alınması talep ediliyordu. Tarikatların kapatılması, tarikatlara bağlı okulların Millî Eğitim Bakanlığı́na devredilmesi, 8 yıllık kesintisiz eğitim, Kur'an kurslarının denetlenmesi, Tevhid-i Tedrisatın uygulanması, irtica nedeniyle ordudan atılanları savunan ve orduyu din düşmanı gösteren medyanın kontrol altına alınması, kıyafet kanununa riayet edilmesi, Atatürk aleyhindeki eylemlerin cezalandırılması, hükümetten uygulanması istenen önlemler arasındaydı. Bu arada Erbakan'ın da istifası istenmişti (Öcal, 2009: 4). İrticai faaliyetlerin takip ve kontrolü amacıyla bu dönemde Batı Çalışma Grubu (BÇG) oluşturuldu. MGK kararlarının uygulanmasını denetlemek üzerek kurulan BÇG, milyonlarca kişi, kurum ve kuruluşla ilgili fişleme çalışmaları yaptı. 
28 Şubat süreci ve Refah Partisi'nin kapatılması, Millî Görüş içinden çıkan ve kendisini yenilikçi olarak lanse eden başka bir siyasi grubun iktidarına giden yolu açmış oldu. Mayıs 1997'de "laikliğe aykırı fillerin odağı olduğu" gerekçesiyle Refah Partisi hakkında kapatma davası açıldı. Erbakan, yaşanan gerginliğin yatıştıııması amacıyla başbakanlık görevini koalisyon ortağı Tansu Çiller'e devretmek üzere 18 Haziran 1997'de istifasını dönemin Cumhurbaşkanı Süleyman Demirel'e sundu. Ancak Demirel hükümeti kurma görevini Çiller yerine dönemin Anavatan Partisi (ANAP) lideri Mesut Yılmaz'a verdi. Refah Partisi, 16 Ocak 1998'de Anayasa Mahkemesi kararıly kapatıldı. (Tunahan, 2015: 23).

Erbakan'ın siyasi yasaklı olduğu dönem Fazilet Partisi'nin 14 Mayıs 2000'de yapılan Birinci Kongresi'nde gelenekçi ve yenilikçi kanatlar arasındaki görüş ayrılıkları açık şekilde belli olmuştu. Erbakan'ın ağırlığı kongrede hissedildi ve gelenekçilerin adayı Recai Kutan, yenilikçilerin adayı Abdullah Gül'ü geride bırakarak genel başkanlık yarışını kazandı. Fazilet Partisi'nin kapatılmasının ardından Recai Kutan liderliğindeki Millî Görüşçüler Saadet Partisi'ne geçti. Yenilikçiler ise 14 Ağustos 2001'de Recep Tayyip Erdoğan, Abdullah Gül, Bülent Arınç gibi isimlerin öncülüğünde Adalet ve Kalkınma Partisi'ni (AKP) kuruldu.

\subsection{Yılı E-Muhtıra}

Genelkurmay Başkanlığı́nın 27 Nisan 2007 gecesi internet sitesi aracılığıyla 11. Cumhurbaşkanı Abdullah Gül'ün, meclis tarafından Cumhurbaşkanı seçilmesi süreci ile ilgili yayınladığı bildiri e-muhtıra olarak değerlendirilmektedir.

2007 yılında Ahmet Necdet Sezer'in Cumhurbaşkanlığı sona ermek üzereydi ve yeni cumhurbaşkanı adayı meclis toplantısında, en fazla sandalye sahibi olan Adalet ve Kalkınma Partisi'nde tarafından belirlendi. Cumhurbaşkanlığı adayının AK Parti tarafından belirlenebilmesi, ordunun müdahaleleri açsından ciddi kaygıya neden oldu. Dönemin Genelkurmay Başkanı General Büyükanıt, 12 Nisan 2007 tarihinde cumhurbaşkanlığı seçimleriyle ilgili olarak "Umarım cumhuriyetin temel değerlerine, devletin üniter yapısına, yani devletin temel değerlerine adanmış bir Cumhurbaşkanı seçilir" sözlerini sarf etti (Hürriyet, 12 Nisan 2007, 1). Bu açıklama, seçimlere ordunun müdahil olacağının bir işareti olarak algılandı. Bu arada Yüksek Mahkeme Savcısı Sabih Kanadoğlu, 28 Aralık 2006 tarihinde, cumhurbaşkanını seçmek için parlamento meclisinin 367'lik bir çoğunluğa sahip olması gerektiğini açıkladı. AK Parti'nin yeterli sayıda milletvekili yoktu ve diğer partilerin meclis oturumuna katılmaması nedeniyle cumhurbaşkanlığı seçimleri gerçekleşmedi (Temiztürk, 2009:1). CHP'de 367'nin altında bir sayıyla yapılacak seçimleri Anayasa Mahkemesi'ne götürmekle tehdit ediyordu (Sabah, 28 Aralık 2006, 1). AK Parti sözcüsü ve bazı siyasi ve hukuki çevrelerde Kanadoğlu'nun ifadesinin bir iddia olarak kabul edildiği ve bunun için yasal bir gerekçe olmadığı vurgulandı. 17 Nisan 2007'de Doğru Yol Partisi lideri Mehmet Ağar ve Anavatan Partisi lideri Erkan Mumcu, cumhurbaşkanlığı seçimleri için işbirliği yapacaklarını açıkladı. Cumhurbaşkanlığı seçim sürecinin başladığı bu ortamda, AK Parti Abdullah Gül'ün Türkiye 11. Cumhurbaşkanı adayı olacağını açıkladı. 27 Nisan 2007 günü saat 15.00'da Türkiye Büyük Millet Meclisi (TBMM) cumhurbaşkanı seçmek için Genel Kurul toplandı. CHP, DYP ve ANAP üyelerinin meclis toplantısının ilk oturumuna katılmama kararı sonucu bazı gelişmeler yaşandı. Cumhurbaşkanlığı seçiminde ilk tur oylamada 361 milletvekili oy kullandı ve cumhurbaşkanı adayı Abdullah Gül 357 oy aldı. Illk turda cumhurbaşkanını seçmek için 367 karar nisabına ulaşılmadığından, süreç ikinci bir tura ertelendi. Bu arada, ana muhalefet partisi CHP, ilk tur oylama için gerekli olan 367 üyenin mevcut olmadığını iddia ederek, Anayasa Mahkemesi'ne oturumu iptal etmek için başvurdu (Temiztürk, 2009: 1). Aynı gün, 27 Nisan 2007 akşamı saat 11: 17'de, Genelkurmay Başkanlığının resmi internet sitesinde bir bildiri yayınladı. Genelkurmay Başkanlığı'nın açıklamasında mevcut durumu kendi bakış açısıyla değerlendirdikten sonra yine laikliğin ihlal edildiğine dair şeriatçı suçlamalarda bulunmuş ve endişelerini dile getirdikten sonra "Unutulmamalıdır ki, Türk Silahlı Kuvvetleri bu tartışmalarda taraftır ve laikliğin kesin savunucusudur. Ayrıca, Türk Silahlı Kuvvetleri yapılmakta olan tartışmaların ve olumsuz yöndeki yorumların kesin olarak karşısındadır, gerektiğinde tavrını ve davranışlarını açık ve net bir şekilde ortaya koyacaktır. Bundan kimsenin şüphesinin olmaması gerekir" sözleriyle siyasal iktidarı darbe ile tehdit etmiştir (Temiztürk, 2009: 1-2). Buna karşılık önceki hükümetlerden farklı olarak AK Parti dik bir duruş sergilemiş ve yaptığı karşı bildiriyle askerleri böyle bir girişime girmemesi karşısında uyararak "sonuçlarına katlanırlar" sözleriyle uyarmıştır. Açıkçası AK Parti hükümeti, önceki hükümetlerden farklı olarak, savunma amaçlı değil de tepkisel bir tavır sergilemiştir. Ayrıca bilim adamlarından ve aydınlara kadar, birçok sivil toplum örgütü ve halk yığınları darbe karşıtı büyük yürüyüşler düzenledi ve orduyu kınadı. Böylece toplum, bu gelişmelerle demokratik bir bilince ulaşmış 
ve demokratik sistemin arkasında durabilmişti. 27 Nisan 2007 tarihli e-mutabakatta hem hükümet hem de sivil toplum tarafından gösterilen tepki, siyasete askeri müdahalenin nefretle karşılandığını ve toplumun böyle girişimlerde sessiz kalmayacağının göstergesi olmuştur. Bu tepkinin sivil-asker ilişkilerinde yeni bir dönem başladığını iddia etmek mümkündür. Askeri yetkililerin kendilerini Türkiye Cumhuriyeti'nin kurucuları olarak algıladıkları ve bu yaklaşımda felsefi bir hareketin olduğu söylenebilir.

\subsection{Temmuz 2016 Kalkışması ve FETÖ}

Türkiye' de parlamenter demokrasi uzunca bir aradan sonra bir kez daha kalkışma ile kesintiye uğratılmak istendi. 15-16 Temmuz 2016 tarihleri arasında Türk Silahlı Kuvvetleri bünyesinde yer alan ve kendilerini Yurtta Sulh Konseyi olarak tanımlayan bir grup asker tarafından gerçekleştirilmeye çalışılan kalkışma Türk Silahlı Kuvvetleri'nin resmî internet sitesi ve TRT' de yayınlanan bildiride ordunun yönetime el koyduğu açıklanmış olup ülkede sıkıyönetim ve sokağa çıkma yasağı ilan edildiği duyurulmuştur. Kalkışma, Türkiye'nin siyasi tarihinde 12 Eylül 1980 askerî darbesinin ardından 36 yıl sonra gerçekleştirilmiş olan ilk doğrudan teşebbüs olarak kayıtlara geçti. 15 Temmuz 2016 Cuma gecesi Fethullahçı Terör Örgütü'ne (FETÖ) bağlı bir takım askerler, bürokratlar, iş adamları akademi ve medyadaki yandaşları tarafından planlanan kalkışma uygulamaya geçirildi. (Karagöl, 2016: 2).

Bu başarısız kalkışma ile hedeflenen amaç, iktidar partisi AK Parti'yi ve lideri Recep Tayyip Erdoğan'ı siyaset sahnesinden silmekti. 17-25 Aralık 2013 eylemleriyle bunu başaramayan FETÖ, 15 Temmuz gecesi TSK'daki unsurlarını emir-komuta zinciri dışında bir darbe için mobilize etmiştir (Melek ve Toker, 2017: 22-230). Söz konusu gece İstanbul'da Boğaziçi Köprüsü'nün bir grup asker tarafından trafiğe kapatılması ile başlamış, Ankara'da jetlerin gece boyunca yaptığı alçak uçuş, TRT'ye el konulması ve darbe bildirisi okunması, Ankara Gölbaşı Özel Harekât Daire Başkanlığı'nın F16'larca bombalanması ve pek çok polisin yaşamını yitirmesi ve sokağa çıkma yasağı ilan edilmesiyle devam etmiştir. Başkent sokaklarında tankların eyleme geçmesi, tank atışlarıyla Ankara Emniyet binasının bombalanması, Marmaris'te tatilde bulunan Cumhurbaşkanı Erdoğan'ın İstanbul'a giderken F-16'lar tarafından taciz edilmesi, TBMM binasının bombalanması gibi olaylarla gerçekleşen darbe girişimi ülkede kaos olması beklenirken toplumsal dayanışmaya ve darbe karşıtı bir sivil toplum eylemine neden olmuştur. 24 saatlik bir süreç dolmadan bastırılan kalkışmada 5 bin 171 kişi gözaltına alınmış, 16 bin 899 kişi tutuklanmış, 76 bin 100 kişi görevden uzaklaştırıımıştır. Kalkışma sırasında 179 sivil, 62 polis ve 5 asker olmak üzere toplam 246 kişi yaşamını yitirmiştir.

Ordu mensuplarından büyük çoğunluğunun karşı durduğu darbe girişimi Cumhurbaşkanı Erdoğan'ın, emniyet güçlerinin, silahlı kuvvetlerin, siyasilerin ve Türk halkının onurlu ve dik duruşu sayesinde bertaraf edilmiştir.

\section{SONUC}

Köklü bir demokrasi geçmişi olmayan, demokrasi kültürü tam olarak gelişmemiş toplumların neredeyse tamamının ortak probleminden birisini asker-sivil ilişkileri oluşturmaktadır. Parlamenter demokrasiyi benimseyen bu toplumlarda yönetimin nasıl olması gerektiği konusunda gerek toplumda gerekse kamu kurumlarında bir mutabakat sağlanamamıştır. Bundan dolayı devlet yönetimi bu tür ülkelerde sarsıntılı bir görünüm sergilemektedir. Askerin müdahaleleri sonucu parlamenter sistem sık sık kesintiye uğramakta, siyasal rejim üzerinde askerin vesayeti söz konusu olmaktadır. Osmanlı Devleti'nden Türkiye Cumhuriyeti'ne uzanan tarihsel süreçte Türk siyasal yaşamı sık sık bu tür müdahalelerle karşılaşmıştır.

Türkiye Cumhuriyeti, Osmanlı Devleti'nden kurumsallaşmış olan bir bürokratik yapı devraldı ve bu yapı aksaklıklarını da beraberinde getirdi. Daha açık söylemek gerekirse, Türkiye II. Meşrutiyetten itibaren oluşmaya başlayan ordu-siyaset ilişkilerini de Osmanlı Devleti'nden miras almış ve ilerleyen zamanlarda siyasal alanda bunların yarattığı sıkıntılar ortaya çıkmıştır. Türkiye, çok partili hayata geçişle birlikte sık sık askerin siyasal rejimin işleyişine müdahalelere şahit olmuş ve parlamenter demokrasi kesintiye uğramıştır. 27 Mayıs 1960 Askeri Darbesi ile başlayan bu süreç 15 Temmuz 2016 ile son bulmuştur.

Hem Osmanlı Devleti'nde hem de Türkiye Cumhuriyeti'nde görülen askerin parlamenter sistemin işleyişine müdahaleleri (15 Temmuz Darbe Girişimi hariç) çoğunlukla bürokrasinin ya da askeri erkânın kendisini halktan ve siyasi iradeden üstün görme gücü çerçevesinde açıklanabilir. Özellikle askeri bürokrasi temel aldığı bazı ilkeler çerçevesinde- Kemalizm, laiklik ve irtica karşıtlığı en belirgin olanlarıdır-siyasi yönetimleri her zaman bir tehdit unsuru olarak görmüş ve kendine göre yeri geldiğinde müdahale etmiştir. 15 Temmuz darbe Girişimi'ne kadar darbelerin bir analize tabi tutulursa, hepsinin Kemalist ideolojiyi kendilerine dayanak olarak seçmişlerdir. Her darbe 
ve darbe girişimi sırasında darbeyi yapanlar, Kemalist ideolojiye sadakatlerini belirttiler ve çalışmalarını Atatürk ilkelerine ve amaçlarına bağlayarak eylemlerini imgelemeye çalıştılar. Birçok sivil grup da bu müdahaleleri destekledi ve Atatürk adına hareket ettiğini iddia etti ya da ismini orduyla birlikte kullandı.

Bazı liderler, askeri müdahaleyi, sevmedikleri, tahammül edemedikleri, aynı dünya görüşünü paylaşmadıkları ve politik arenada alt edemedikleri politikacılara karşı son çare olarak gördüler. Askeri darbeler bazen 1960 darbesi örneğinde olduğu gibi ordunun içindeki cuntalar tarafından ya da bazen 1980 darbesinde olduğu gibi bütünsel olarak ordunun içindeki emir- komuta zinciriyle gerçekleştirildi. Darbe uygulayıcılarının ifadelerine göre, darbeler "laikliği korumak, modern bir medeniyet seviyesine ulaşmak, komünizme ve gericiliğe karşı savaşmak; kargaşa, bozukluk, anarşi, iç çatışma önlenmesi; demokrasiyi korumak ve kurmak" amacını güdüyordu.

Yapılan birçok askeri darbe girişimi ülkede çıkan çatışmaları bahane etmiştir. Ayrıca dünyada ve Türkiye'de yaşanan hızı değişimin sistem üzerinde yarattığı baskılar ve yeni taleplere siyasal sistemin cevap veremediği, siyasi kurumların sorun çözme noktasında yetersiz kaldıkları, özellikle Silahlı Kuvvetlerin taleplerinin karşılanamadığı dile getirilmektedir. Bütün bunların yanında terör ve anarşi ile ekonomik sorunların yarattığı istikrarsız yapıda demokratik kurum ve süreçlerin sorun çözme konusundaki yetersizliği darbeyi yaratan nedenler arasında sayılmıştır.

15 Temmuz Darbe Girişimi, yukarıda sayılan nedenlerden tamamen farklıdır. Çünkü yukarıda sayılan nedenlerden tamamen farklı gerekçelere dayanmaktadır. Devlet içinde yapılanmış ve gizlice örgütlenmiş bir terör örgütünün (Paralel Devlet Yapılanması) faaliyete geçmesinden ibarettir. Daha önceki darbeler ya da darbe girişimlerine göre çok farklı sonuçlar doğurmuştur. Sonuç olarak yaşanan FETÖ'nün 15 Temmuz darbe girişimi, toplumdaki demokratik kültür ve davranışların canlanmasını sağladı. Tüm vatandaşlar hükümetiyle muhalefetiyle Türkiye için birleşmesini sağladı. Sivil toplumun siyasal iktidarı koruyan bir kalkana dönüştüğüne şahit olundu. Öte yandan, parlamentonun içinde ve dışında birçok parti, iktidar partisine muhalefetiyle tanınan milyonlarca vatandaşla birlikte, mücadelede parlamenter demokrasi için ayağa kalktı. 


\section{KAYNAKÇA}

Akbal, İ., Çınarlı, Ö., Safi, İ. (2018). Sadrazam Mahmut Şevket Paşa Suikasti'nin İngiliz Basınına Yansımaları ve İngiltere- Osmanlı Devleti İlişkilerine Etkileri. Uluslararası EMI Sosyal Bilimler Kongresi, 27-29 Nisan 2018, Lefkoşa.

Akıncı, A. (2017). Türkiye'nin Darbe Geleneği: 1960 ve 1971 Müdahaleleri. Eskişehir Osmangazi Üniversitesi İktisadi ve İdari Bilimler Dergisi, (9/1), 55-72.

Akyüz, Y. (1989). Atatürk Illkeleri ve Inkılap Tarihi, Ankara: YÖK Yayınları.

Atay, A. S. (1998). Çok Partili Dönemde Türkiye'de Ordunun Siyasal Rolü ve Devlet Yapısı İçindeki Yeri, Eskişehir: Anadolu Üniversitesi Yayınları.

Aydemir, Ş. S. (1993). Enver Paşa. İstanbul: Remzi Kitabevi.

Birecikli, İ. B. (2012). Sultan II. Abdülhamit'e Karşı Başarısız Bir Darbe Teşebbüsü. Journal of Life Sciences, (1/1), 683-696.

Birinci, A. (1990). Hürriyet ve İtilâf Fırkası: Il. Meşrutiyet Devrinde Ittihat ve Terakki'ye Karşı Çıkanlar. İstanbul: Dergâh Yayınları.

Börklüoğlu, L. (2017). 27 Mayıs Askeri Darbesi Sonrasında Ordu İçinde İktidar Mücadelesi: Milli Birlik Komitesi ve Silahlı Kuvvetler Birliği. Osmaniye Korkut Ata Üniversitesi Iktisadi ve Idari Bilimler Fakültesi Dergisi, (1/2), 13-28.

Çakmak, D. (2015). Türkiye'de Asker-Hükümet Illişkisi: Albay Talat Aydemir Örneği, Gazi Akademik Bakış Dergisi, (1/2), 35-68.

Demir, Y. (2006). Albay Talat Aydemir'in Darbe Girişimleri. Çağdaş Türkiye Tarihi Araştırmaları Dergisi, (5/13), 155-171.

Devran, Y. ve Özcan, F. (2016). 1960'tan 2016'ya Asker Darbe ve Muhtıra Metinleri, Anlamlar, Amaçlar, Niyetler ve İdeolojiler. İnönü Üniversitesi İletişim Fakültesi Dergisi, (1/2), 9-20.

Dursun, D. (2004). Siyaset Bilimi. İstanbul: Beta Yayınları.

el-Nawawy, M. and Elmasry, M. H. (2016). The Signs of a Strongman: A Semiotic and Discourse Analysis of Abdelfattah Al-Sisi's Egyptian Presidential Campaign. International Journal of Communication, (10), 2275-2296.

Eraslan, C. (1996). Sultan İkinci Abdülhamid, İstanbul: Nesil Yayınları.

Feroz, A. (2012). Modern Türkiye'nin Oluşumu. (Çev. Yavuz Alogan), İstanbul: Kaynak Yayınları.
Feroz, A. (2013). İttihat ve Terakki (1908-1914). (Çev. Nuran Yavuz), İstanbul: Kaynak Yayınları.

Heper, M. (1998). Türkiyénin Siyasal Hayatı. İstanbul: Doğan Yayıncılık.

Hürriyet, 12 Nisan 2007.

Karagöl Erdal Tanas (2016), "15 Temmuz Darbe Girişimi ve Türkiye Ekonomisi", Adam Academy Journal Of Social Sciences/Adam Akademi Sosyal Bilimler Dergisi, C:6, S:2. Nisan 2016 s.1-20.

Karal Enver Ziya (1988), Osmanlı Tarihi, Türk Tarih Kurumu Yay, Ankara.

Kayalı Kurtuluş (1994), Ordu ve Siyaset: 27 Mayıs-12 Mart, İletişim Yay, İstanbul.

Melek Gizem ve Huriye Toker (2017), "Şiddet, Demokrasi ve Terör Bağlamında Ana Akım Medyanın Analizi: 15 Temmuz Darbe Girişimi", Erciyes İletişim Dergisi, Cilt (Volume): 5, Sayı (Number): 1, Kayseri, .222-234.

Öcal Beyhan (2009), "12 Eylül'den 28 Şubat'a Darbe Söylemlerindeki Değişimin Analizi" Dialogues in Philosophy and Social Sciences, January 2009, Volume 1/4, Antalya, s.1-60.

Önal Tekin (2017), “27 Mayıs İhtilali'nin Geride Bıraktıkları ve İnönü Hükümetleri Döneminin Önemli İç Siyasi Gelişmeleri (1961-1965)", Maarif Mektepleri Uluslararası Sosyal ve Beşeri Bilimler Dergisi, S: 1 (1), Ankara, s.10-25.

Sabah, 28 Aralık 2006.

Sarıca, Murat (1995), 100 Soruda Fransız İhtilali, Gerçek Yay, İstanbul.

Temiztürk Hakan (2009), "Türkiye'de Ordunun Siyasete Müdahale Geleneği ve Basın: 27 Nisan 2007 Muhtırasından Önce ve Sonra", Erciyes iletişim Dergisi, C: 1, S: 1, Kayseri, s.6-23.

Toker Metin (1991), Demokrasimizin İsmet Paşalı Yılları 1944-1973, Bilgi Yay, Ankara.

Tunahan Özcan (2015), “28 Şubat Süreci: 'Post-Modern Darbe'nin Sosyo-Politik Dinamikleri ve Toplum Desteği", Bilgi, Cilt: 17, S:1, s. 23-41.

Tunaya Tarık Zafer (1995), Türkiye'de Siyasal Partiler, İletişim Yay, İstanbul,

Tursun, Soner (2013), II. Meşrutiyet'in İlanı ve 31 Mart Olayı, Trakya Üniversitesi, SBE, Basılmamış Yüksek Lisans Tezi, Edirne.

Yalçın Hüseyin Cahit (2000), Siyasal Anılar, Tiş Yay, İstanbul. 
Yetkin Çetin (2006), Türkiye'de Askeri Darbeler ve Amerika: 27 Mayıs 1960-12 Mart 1971-12 Eylül

1980, Müdafaa-i Hukuk Yay, Ankara. 